\title{
5: $132327181-132244244$
}

National Cancer Institute

\section{Source}

National Cancer Institute. 5: 132327181-132244244. NCI Thesaurus. Code C41666.

Physical location of AF5Q31_Gene 